\section{Spontaneous Elimination of HCV during the Reactivation of HBV Infection in a HIV-Seropositive Patient: A Case Report}

\author{
Christel Pissier \\ Laboratory of Pharmacokinetics and \\ Toxicology, La Timone University Hospital, \\ Marseille, France
}

\section{Corresponding author: $\mathrm{C}$ Pissier}

\section{Abstract}

The course of hepatitis $\mathrm{C}$ virus (HCV) infection varies widely after initial exposure. Two-third of individuals have persistent viremia and develop chronic hepatitis C. In HCV chronically-infected patients, spontaneous HCV clearance occurs in approximately $0.5 \% /$ individual/year. All the case reports describing this fact are associated with changes in host immunity.

We report a case of HCV RNA spontaneous clearance concurrently with hepatitis $B$ virus (HBV) reactivation in a patient infected with the human immunodeficiency virus type 1 (HIV-1) and chronically-infected with HCV. Serum HCV RNA became undetectable at diagnosis of $\mathrm{HBV}$ reactivation. Nine months after acute hepatitis, serum HBV DNA was no more detectable but HCV RNA load was found to rise again to its pre-hepatitis level.

\section{झ christel.pissier@ap-hm.fr}

Pharm D, Laboratory of Pharmacokinetics and Toxicology, La Timone University Hospital, Assistance Publique des Hôpitaux de Marseille, 264 rue Saint-Pierre, 13385 Marseille cedex 05, France

Tel: +33(0)491387565

Fax: +33(0)491387883

\section{Introduction}

Seventy to eighty percent of patients infected with hepatitis $\mathrm{C}$ virus (HCV), defined by the persisting presence of serum HCV RNA more than 6 months, develop a chronic infection, whereas $20-30 \%$ of patients clear HCV RNA shortly after onset of acute infection [1]. In contrast, spontaneous healing has been scarcely reported once chronic infection is established, occurring in approximately $0.5 \% /$ individual/year [2].

The several case reports describing this fact are associated with changes in host immunity like development of hepatocellular carcinoma, pregnancy, immunesuppressive therapy after liver transplantation, gastrectomy for gastric cancer and immune reconstitution following treatment by protease inhibitor for HIV infection [2-6].

We report a case of HCV RNA spontaneous clearance concurrently with hepatitis $B$ virus (HBV) reactivation in a patient infected with the human immunodeficiency virus type 1 (HIV-1) and chronically-infected with HCV.

\section{Case Report}

Our patient is a 49-year-old male co-infected with HIV-1 and $\mathrm{HCV} /$ genotype $3 a$ since at least 6 years. His HBV serological status indicated an isolated antibody against HBV core antigen (anti-
$\mathrm{HBC}$ ) which is indicative of resolved HBV infection (Axsym Abbott assays, Abbott Diagnostics).

Despite several antiretroviral combination regimen, HIV-1 replication remained detectable (using Cobas HIV-1 Taqman Roche assay, Roche Diagnostics; lower limit of detection, 40 copies/ml) since 18 months, whereas the CD4 cells count slowly decreased until $216 / \mathrm{mm}^{3}$. Concomitantly, HCV RNA level was $6.20 \log _{10} \mathrm{IU} / \mathrm{mL}$ (Cobas HCV Taqman Roche assay, Roche Diagnostics).

Six months later, the patient presented acute hepatitis with jaundice. Alanine aminotransferases (ALT) and bilirubinemia increased within $40(1,931 \mathrm{IU} / \mathrm{L})$ and 8 times $(150 \mu \mathrm{mol} / \mathrm{L})$ the upper limit of normal, respectively; prothrombin time fall to $66 \%$. HBV reactivation was diagnosed based on high HBV DNA levels (7.81 $\left.\log _{10} \mathrm{IU} / \mathrm{mL}\right)$, and HBsAg and anti-HBc Immunoglobilin (Ig) type $M$ positivity. Phylogenetic analysis of HBV DNA pol sequences retrieved a genotype D. Surprisingly, concomitantly with the rise of HBV DNA, serum HCV RNA decreased from an initial $5.15 \log _{10} \mathrm{IU} / \mathrm{mL}$ to undetectable levels (as assessed five weeks following clinical onset of hepatitis), without any anti-HCV treatment, but anti-HCV stayed positive. HIV-1 load was $3.46 \log _{10}$ copies/mL and CD4 cells counts was $424 / \mathrm{mm}^{3}$.

Retrospective analyses were performed to obtain the kinetic of both HBV DNA and HCV RNA measurements in serum from 18 
months to prior to the clinical onset of hepatitis. They showed that HBV DNA remained undetectable in serum until the diagnosis of reactivation (lower limit detection, $6 \mathrm{IU} / \mathrm{mL}$ ).

HCV RNA remained undetectable on three consecutive samples during a one-month period. Then the patient only came back to hospital nine months later, and unfortunately, his HCV RNA load was found to have risen again to its pre-hepatitis level $\left(6.20 \log _{10}\right.$ $\mathrm{IU} / \mathrm{mL}$ ). In contrast, HBV DNA was no more detectable with ultrasensitive assays, and HBsAg had been cleared. ALT remained above the normal values, at $144 \mathrm{IU} / \mathrm{L}$.

\section{Discussion}

This report documents the clearance of both: hepatitis $B$ and $C$ viruses in a HIV-1 seropositive patient suffering from chronic HCV infection and relapsing from HBV infection.

Co-infection of other viruses, especially HIV-1 and HBV, has been shown to modify the natural course of HCV infection [7,8]: co-infection of HIV-1 is associated with significantly lower spontaneous HCV clearance, while chronic infection with HBV is associated with significantly higher spontaneous clearance [911].
Up to now the natural course of HBV reactivation in patients with chronic HCV hepatitis has remained unclear and no data is available. The few cases of patients describing a spontaneous elimination of both HCV during chronic infection and HBV provide an acute HBV infection in HIV-seronegative patients [12-15]. In these cases, the patients were negative for HCV RNA for 6 months at least, such as our patient.

Unlike our case, a study of hemophiliac subjects had shown that resolved HBV infection was not associated with spontaneous clearance of HCV contrary to chronic HBV disease [16].

The mechanisms of the reciprocal inhibition in viral replication between HBV and HCV in patients co-infected with these two viruses are not clear but scientists hypothesize a specific humoral $T$ cell response by HBV superinfection against HCV $[12,13]$.

\section{Conclusion}

We recommend the monitoring of HCV RNA in sera of HCV chronically-infected patients during hepatitis $B$ reactivation or superinfection, to detect potential HCV clearance. 


\section{References}

1 Scott JD, McMahon BJ, Bruden D, Sullivan D, Homan C, et al. (2006) High rate of spontaneous negativity for hepatitis $C$ virus RNA after establishment of chronic infection in Alaska Natives. Clin Infect Dis 42: 945-952.

2 Yokosuka O, Kojima H, Imazeki F, Tagawa M, Saisho H, et al. (1999) Spontaneous negativation of serum hepatitis $C$ virus RNA is a rare event in type $C$ chronic liver diseases: analysis of HCV RNA in 320 patients who were followed for more than 3 years. J Hepatol 31: 394-399.

3 Zein CO, Abu-Lebdeh H, Zein NN (2001) Spontaneous clearance of chronic hepatitis $C$ during pregnancy. Am J Gastroenterol 96: 30443045.

4 Samonakis DN, Cholongitas E, Triantos CK, Griffiths P, Dhillon AP, et al. (2005) Sustained, spontaneous disappearance of serum HCVRNA under immunosuppression after liver transplantation for HCV cirrhosis. J Hepatol 43: 1091-1093.

5 Yoshikawa M, Morimoto Y, Shiroi A, Yoshiji H, Kuriyama S, et al. (2001) Spontaneous elimination of serum HCV-RNA after total gastrectomy for early gastric cancer in a patient with chronic hepatitis C. Am J Gastroenterol 96: 922-923.

6 Fialaire P, Payan C, Vitour D, Chennebault JM, Loison J, et al. (1999) Sustained disappearance of hepatitis $C$ viremia in patients receiving protease inhibitor treatment for human immunodeficiency virus infection. J Infect Dis 180: 574-575.

7 Thomas DL, Astemborski J, Rai RM, Anania FA, Schaeffer M, et al. (2000) The natural history of hepatitis $C$ virus infection: host, viral, and environmental factors. JAMA 284: 450-456.

8 Soriano V, Mocroft A, Rockstroh J, Ledergerber B, Knysz B, et al. (2008) Spontaneous viral clearance, viral load, and genotype distribution of hepatitis C virus (HCV) in HIV-infected patients with anti-HCV antibodies in Europe. J Infect Dis 198: 1337-1344.

9 Ohkawa K, Hayashi N, Yuki N, Masuzawa M, Kato M, et al. (1995) Long-term follow-up of hepatitis B virus and hepatitis $C$ virus replicative levels in chronic hepatitis patients coinfected with both viruses. J Med Virol 46: 258-264.

10 Zarski JP, Bohn B, Bastie A, Pawlotsky JM, Baud M, et al. (1998) Characteristics of patients with dual infection by hepatitis $B$ and $C$ viruses. J Hepatol 28: 27-33.

11 Sagnelli E, Coppola N, Pisaturo M, Masiello A, Tonziello G, et al. (2009) HBV superinfection in HCV chronic carriers: a disease that is frequently severe but associated with the eradication of HCV. Hepatology 49: 1090-1097.

12 Gruener NH, Jung MC, Ulsenheimer A, Gerlach TJ, Diepolder HM, et al. (2002) Hepatitis $C$ virus eradication associated with hepatitis $B$ virus superinfection and development of a hepatitis $B$ virus specific $T$ cell response. J Hepatol 37: 866-869.

13 Wietzke P, Schott P, Braun F, Mihm S, Ramadori G (1999) Clearance of HCV RNA in a chronic hepatitis $C$ virus-infected patient during acute hepatitis B virus superinfection. Liver 19: 348-353.

14 Guido M, Rugge M, Colombari R, Cecchetto A, Scarpa A, et al. (1998) Prompt hepatitis $C$ virus suppression following hepatitis $B$ virus superinfection in chronic untreated hepatitis C. Ital J Gastroenterol Hepatol 30: 414-417.

15 Sagnelli E, Coppola N, Messina V, Di Caprio D, Marrocco C, et al. (2002) HBV superinfection in hepatitis $C$ virus chronic carriers, viral interaction, and clinical course. Hepatology 36: 1285-1291.

16 Zhang M, Rosenberg PS, Brown DL, Preiss L, Konkle BA, et al. (2006) Correlates of spontaneous clearance of hepatitis $C$ virus among people with hemophilia. Blood 107: 892-897. 